\title{
МЕТОДИКА І ОРГАНІЗАЦІЯ ДОСЛІДЖЕННЯ ЛІДЕРСЬКОГО ПОТЕНЦІАЛУ ДІТЕЙ СТАРШОГО ДОШКІЛЬНОГО ВІКУ О. К. Безсонова
}

\author{
THE METHODOLOGY AND ORGANIZATION OF LEADERSHIP \\ POTENTIAL RESEARCH IN CHILDREN OF SENIOR PRESCHOOL AGE \\ O. Bezsonova
}

\begin{abstract}
У статті проведено теоретичну розвідку щодо визначення критеріїв, показників та рівнів сформованості лідерського потенціалу дітей старшого дошкільного віку. Доведено відсутність єдності думок науковців щодо формування набору критеріїв для оцінки сформованості лідерського потенціалу. Навпаки, арсенал критеріїв та показників досить різноманітний (когнітивний, діяльнісний, комунікативний, рефлексивний, емоційно-ціннісний тощо). У більшості праць досліджується лідерський потенціал керівників установ, лідерів місцевого самоврядування, лідерів студентського активу, державних службовців та військових. Практично відсутні дослідження критеріїв та показників сформованості лідерського потенціалу дітей старшого дошкільного віку. Визначено критерії та показники сформованості лідерського потенціалу дітей старшого дошкільного віку: особистісний (широкий світогляд, базові особистісні якості, здатність особистості до аналізу результатів діяльності та подальшого формулювання перспектив), креативно-діяльнісний (прагнення лідерської позиції у дитячій спільноті, відчуття новизни та креативний підхід до діяльності, лідерська поведінка), комунікативний (здатність до налагодження комунікації, чутливість до емоцій своїх власних та оточення), соціальний (здатність до партнерської взаємодії та досягнення взаєморозуміння, адаптивність поведінки). Визначено рівні розвитку лідерського потенціалу дітей старшого дошкільного віку: творчий, адаптивний, елементарний. На основі виокремлених критеріїв і показників надано змістовні характеристики рівнів.

Ключові слова: діти, старший дошкільний вік, лідерський потенціал, якості особистості, міжособистісна взаємодія, вмотивованість діяльності, критерії, показники, рівні.
\end{abstract}

The article conducts theoretical research to determine the criteria, indicators, and levels of leadership potential in senior preschool children. The lack of unity of the scientists' ideas considering the development of criteria set for assessing the leadership potential development is proved. In contrast, the arsenal of criteria and indicators is diverse (cognitive, activity, communicative, reflexive, emotional-value, etc.). Most of the papers explore the leadership potential of heads of institutions, local government leaders, student leaders, civil 
servants, and the military. There are almost no studies of criteria and indicators of leadership potential development in senior preschool children. Criteria and indicators of leadership potential development in senior preschool children are determined: personal (broad worldview, basic personal qualities, ability of the individual to analyze the results of activities and further formulation of prospects), creative (aspiration of leadership position in the children's community, sense of novelty and creative approach to activities, leadership behavior), communicative (ability to establish communication, sensitivity to emotions of their own and others), social (ability to partner and achieve mutual understanding, adaptability of behavior). Levels of leadership potential development in children of senior preschool age are defined: creative, adaptive, elementary. The meaningful characteristics of levels are given based on the selected criteria and indicators.

Keywords: children, senior preschool age, leadership potential, personality qualities, interpersonal interaction, activity motivation, criteria, indicators, levels.

Постановка проблеми. На нинішньому етапі розвитку нашої держави сучасний лідер має буди здатен гнучко і швидко адаптуватися до умов сьогодення, володіти високорозвиненим інтелектом, бути ініціативним, діяльним, активним, вміти представляти спільні інтереси тощо (Буряк, 2009; Калашнікова, 2010a; Луговий, Калашнікова, Слюсаренко, \& Таланова, 2014; Нестуля, 2010; Сурай, 2011; Яхнін, 2010; Blank, 1995 та ін.).

Сучасні науковці-педагоги і психологи все частіше говорять про гостру необхідність розвитку лідерського потенціалу у дітей, починаючи вже 3 дошкільного віку (Гавриш, Безсонова, Безрукова, \& Воронов, 2020; Гавриш, \& Воронов, 2016; Гавриш, 2017; Іванова, 2014). Молодій людині в XXI столітті конче потрібні яскраво виражені організаторські навички, адекватна реакція на зміни, внутрішнє прагнення до соціальної активності, здатність до детального аналізу інформації заради досягнення поставлених цілей.

Аналіз останніх досліджень і публікацій. У дослідженнях лідерства, зокрема у визначенні критеріїв та показників сформованості здебільшого увагу зосереджено на: розвитку лідерських якостей у майбутніх керівників (Головешко, 2016; Драч, 2015; Калашнікова, 2010b; Локшин, 2013; Скібіцька, 2009; Яценко, 2016; Balci, 2017; Blank, 1995); дослідженнях формування лідерства у студентському середовищі (Кращенко, 2011; Мараховська, 2009; Романовський, \& Резнік, 2017; Balci, 2017;); лідерських якостях педагогів та їх формуванні (Кращенко, 2011; Мараховська, 2009 та ін.); вихованні лідерських якостей особистості в системі загальної середньої освіти (Алфімов, 2014; , Клепко, \& Литвинюк, 2012; С. Кові, Ш. Кові, Самерз, \& Хетч, 2016; Петрочко, 2014; $\quad$ Приходько, 2008; $\quad$ Ротко, 2017; $\quad$ Семенов, 2014; 
Шевчук, 2016; Ягоднікова, 2009 та ін.); досліджень щодо лідерства як основної категорії менеджменту (Локошко, 2008; Луговий, Калашнікова, Слюсаренко, \& Таланова, 2014; Прохоренко, Зборовська, \& Носирєва, 2008; К. Садохіна, 2010; Татенко, 2006; Тихомирова, 2009; Яценко, 2016; Blank, 1995).

У дослідженнях лідерських проявів найчастіше дослідники виокремлюють такі критерії: мотиваційний/мотиваційно-цуіннісний (Волківська, 2016; Мараховська, 2009; Мороз, 2019 та ін.); комунікативний (Мороз, 2019 та ін.); когнітивний (Волківська, 2016; Мараховська, 2009; Кращенко, 2011; Мороз, 2019 та ін. ); діяльнісний (Волківська, 2016 та ін.); рефлексивний (Волківська, 2016; Іванова, 2014; Кращенко, 2011); емоиійноиіннісний (Кращенко, 2011 та ін.).

Цікавою вважаємо думку Я. Яхніна, який пропонує такі критерії оцінки лідерства: прагнення вести за собою, мотивація першості, впливовість, занурення й закоханість у власну справу, компетентність і креативність, психологічна надійність, адекватна самооцінка й саморегуляція, самовдосконалення (Яхнін, 2010).

Ю. Кращенко (2011) серед критеріїв вихованості лідерських якостей майбутніх учителів у системі студентського самоврядування виокремлює когнітивний, емоційно-ціннісний, професійно-діяльнісний, саморегуляційно-рефлексивний.

Н. Мараховською також уточнено критерії та показники сформованості лідерських якостей майбутніх учителів: мотиваційний (прагнення стати лідером у педагогічній діяльності), когнітивний (характер засвоєння знань про лідерство в педагогічній діяльності); операційний (лідерські вміння - організаторські, комунікативні, перцептивні, прогностичні, креативні, саморегуляції); контрольно-корегувальний (забезпечує збереження стійкої лідерської позиції, яка відображається в самовираженні лідерських якостей у педагогічному процесі, подоланні перешкод, що заважають самореалізації в лідерстві) (Мараховська, 2009).

У площині дослідження формування лідерського потенціалу саме дошкільників працює авторський колектив на чолі з Н. Гавриш (Гавриш, Безсонова, Безрукова, \& Воронов (2020). Науковці фокусують увагу на таких критеріях: прагнення лідерської позиції у дитячій спільноті (вмотивованість); навички командної взаємодії і комунікації (уміння і навички конструктивної взаємодії); базові особистісні якості (важливі для лідерства). Показники сформованості лідерського потенціалу за 
виокремленими критеріями у програмі «Лідер живе у кожному» визначено за всіма видами діяльності (ігровою, господарсько-побутовою, пізнавальною, комунікативною, дослідницько-пошуковою, художньоестетичною, руховою) (Гавриш, Безсонова, Безрукова, \& Воронов, 2020).

Аналіз літературних джерел дає підставу стверджувати, що психодіагностичний інструментарій, спрямований на визначення рівня сформованості лідерського потенціалу дошкільників, на даний час не можна вважати остаточно сформованим. Саме тому метою статті стало висвітлення процесу відбору критеріїв та створення ефективного комплексу валідних і надійних діагностичних методів, спрямованих на визначення показників та рівнів розвитку лідерського потенціалу дітей старшого дошкільного віку.

Виклад основного матеріалу дослідження. На основі проведеного змістовно-структурного аналізу ключового поняття нашого дослідження та схарактеризованих структурних компонентів (Безсонова, 2020) було визначено критеріальну базу та дібрано діагностичні методики для визначення рівнів розвитку лідерського потенціалу дітей старшого дошкільного віку. У сучасній педагогічній науці не існує єдиного розуміння сутності показників та критеріїв розвитку лідерського потенціалу дітей цієї вікової категорії. У результаті проведеного аналізу нами було сформовано власне бачення критеріального апарату відповідно до завдань нашого дослідження.

На основі проведеного теоретичного аналізу було визначено такі критерії розвитку лідерського потенціалу дітей старшого дошкільного віку: особистісний, креативно-діяльнісний, комунікативний, соціальний. Охарактеризуємо показники кожного критерію.

Особистісний критерій розвитку лідерського потенціалу дітей старшого дошкільного віку характеризує сформованість базових особистісних якостей, важливих для лідерства, та здатність особистості до самоідентифікації і саморозвитку. Показники цього критерію: широта світогляду, сформованість базових особистісних якостей (важливих для лідерства), здатність особистості до аналізу результатів діяльності та формулювання подальших перспектив.

Креативно-діяльнісний критерій характеризує оволодіння старшим дошкільником сукупністю дій та операцій, що забезпечують розв'язання стандартних і нестандартних ситуацій у практичній діяльності; вмінь та навичок, якість засвоєння й узагальнення яких необхідні для 
здійснення ефективної лідерської діяльності. Нами було виокремлено такі показники креативно-діяльнісного критерію як: прагнення лідерської позииіі у дитячій спільноті (вмотивованість), відчуття новизни та креативний підхід до діяльності, лідерська поведінка.

Комунікативний критерій характеризує вміння налагодити взаємодію з усіма учасниками освітнього процесу, переконувати інших, впевнено відстоювати свою позицію, вміння встановлювати контакт 3 партнерами по спілкуванню 3 метою налагоджування результативної взаємодії. Нами було виокремлено такі показники комунікативного критерію як: здатність до налагодження комунікації, чутливість до емоиій своӥх власних та оточення.

Соціальний критерій характеризує здатність дитини старшого дошкільного віку брати активну участь у груповій (командній) взаємодії: ініціювати, домовлятися, розподіляти обов'язки, виконувати спільні дії та досягати бажаного результату. Нами було виокремлено такі показники соціального критерію як: здатність до партнерської взаємодії та досягнення взаєморозуміння, адаптивність поведінки.

На основі показників кожного критерію нами були виведені рівні розвитку лідерського потенціалу дітей старшого дошкільного віку: творчий, адаптивний, елементарний.

Схарактеризуємо рівні розвитку лідерського потенціалу дітей старшого дошкільного віку:

\section{Особистісний критерій}

Творчий рівень:

- дитина яскраво проявляє інтелектуальні здібності, широкий (для свого віку) світогляд, різнобічні знання, постійно готова знайти і дати відповідь на будь-яке запитання;

- дитина в повній мірі демонструє ініціативність, гнучкість, пильність, творчість, чесність, сміливість, впевненість у власних силах i можливостях, урівноваженість, незалежність, мобільність, самостійність, наполегливість, впертість, комунікабельність, енергійність, працездатність, прагнення до переваги, обов'язковість, відповідальність;

- адекватно сприймає себе, власні внутрішні стани і різні ситуації життя;

- суспільно-значущі мотиви та цінності переважають над особистісними, що виявляється в бажанні зробити щось значуще для інших; 
- уміє визначати й аналізувати причини своєї поведінки, iï результативні параметри i допущені помилки; долати труднощі, прогнозувати наступний хід подій i потрібні дії, повертатися назад i оцінювати правильність обраного плану.

Адаптивний рівень:

- ситуативно проявляє інтелектуальні здібності, світогляд обмежений власними інтересами, знання однобічні, готовність знайти i дати відповідь на будь-яке запитання виявляється ситуативно;

- дитина не завжди демонструє впевненість у власних силах i можливостях, урівноваженість, незалежність, мобільність, самостійність, потребу в досягненнях, наполегливість і впертість, комунікабельність, енергійність, працездатність, прагнення до переваги, обов'язковість, відповідальність;

- здатність пред’являти вимоги до себе та реально оцінювати власні можливості розвинута не достатньо;

- суспільно-значущі та особистісні мотиви рівнозначні, що виявляється в бажанні зробити щось значуще як для себе, так і для інших;

- імпульсивно оцінює і вирішує ситуації, не вміє з'ясовувати причини виникнення проблем, критичне мислення відсутнє.

Елементарний рівень:

- світогляд украй обмежений, знання поверхові, бажання пізнавати щось нове відсутне;

- відсутні впевненість у власних силах і можливостях, урівноваженість, незалежність, мобільність, самостійність, наполегливість, комунікабельність, енергійність, працездатність, обов'язковість, відповідальність;

- аналіз своїх можливостей необ'єктивний, відсутнє вміння встановлювати причинно-наслідкові зв'язки і визначати цілі;

- дитина відчуває страх перед самостійним розв'язанням проблемних ситуацій, не спроможна коректувати свою поведінку і бачити кінцеву мету власної діяльності;

- супідрядність мотивів дитини не набуло постійного характеру, у більшості випадків вона керується особистими інтересами, суспільно значущі мотиви виражені недостатньо.

\section{Креативно-діяльнісний критерій}

Творчий рівень:

- у дитини сильно виражена мотивація до успіху й наполегливість у 
досягненні мети;

- наявна реалістичність i практичність у постановці цілей, планування та прогнозування позитивних результатів, визначення засобів для їх досягнення, яскраво виражена потреба у змінах;

- швидко та зважено приймає рішення у стандартних та складних ситуаціях;

- рівень прояву здатності генерувати нові ідеї та творчо їх реалізувати в різних видах діяльності, прояву винахідливості, продукування нестандартних рішень високий;

- намагається завжди доводити розпочату справу до кінця, проявляє позитивні емоції у процесі досягнення мети;

- завдяки обізнаності в різних сферах знань дитина має авторитет, який впливає на дії інших дітей.

Адаптивний рівень:

- у дитини слабо виражена мотивація до успіху й наполегливість у досягненні мети;

- у постановці цілі відсутня стабільність (залежність від умов), не системно планує та прогнозує результати, визначає засоби для їх досягнення, наявна потреба у змінах;

- рішення приймає як зважено, так i імпульсивно, гнучкість у прийнятті й коригуванні рішень відсутня;

- дитина проявляє винахідливість лише у сферах, у яких зацікавлена; в інших випадках винахідливість не супроводжується ініціативністю, а тому здебільшого не реалізується;

- періодично доводить розпочату справу до кінця, відсутні особливі емоції у процесі досягнення мети;

- завдяки обізнаності в певній сфері знань має ситуативний авторитет, який впливає на дії інших дітей.

Елементарний рівень:

- прагнення до самовияву відсутні, переважає мотивація уникнення невдач;

- постановки цілі, планування та прогнозування результатів, визначення засобів для їх досягнення, потреби у змінах відсутні;

- наявні постійні вагання й імпульсивність під час прийняття рішень (рішення або залишаються незмінними за необхідності коригування, або скасовуються);

- дитина виявляє розгубленість у ситуації невизначеності, продукує 
лише стандартні рішення, не вірить у свої творчі здібності, дотримується лише традиційного способу дій та усталених норм;

- намагання доводити розпочату справу до кінця відсутні, проявляються негативні емоції у зв'язку з потребою вчиняти дії для досягнення мети;

- через відсутність обізнаності в певній сфері знань дитина не має авторитету, не впливає на дії інших дітей.

\section{Комунікативний критерій}

Творчий рівень:

- коло спілкування широке i постійно зростає, дитина вміє знаходити спільну мову з новими людьми, постійно прагне до спілкування;

- вміє ясно і чітко висловлювати думки, доносити їх до інших, переконувати у власній правоті, відстоювати і доводити власну точку зору за допомогою достатньо вагомих аргументів;

- постійно контролює зовнішні прояви власних емоцій чи поведінки (активізує, підтримує або деактивує);

- активно використовує ефективні методи виходу зі стресових, конфліктних i кризових ситуацій, використовує тактики розумного переконання.

Адаптивний рівень:

- наявне стале коло спілкування, надає перевагу старим друзям i знайомим, уміє знаходити спільну мову з новими людьми, прагне до спілкування;

- вміє відстоювати власну точку зору, але часто не вміє наводити переконливі аргументи;

- сформована здатність до періодичного чи нетривалого контролю (активізації, підтримки або деактивації) зовнішнього прояву власних емоцій чи поведінки;

- не завжди уміє використовувати ефективні методи виходу зі стресових, конфліктних і кризових ситуацій, використовувати тактики розумного переконання.

Елементарний рівень:

- коло спілкування вузьке, не вміє знаходити спільну мову з новими людьми, прагне до усамітнення;

- не вміє відстоювати власну точку зору;

- дитина не здатна контролювати зовнішні прояви власних емоцій, не вміє активізувати, підтримати або деактивувати власні емоції чи 
поведінку;

- не завжди вміє використовувати ефективні методи виходу зі стресових, конфліктних i кризових ситуацій, використовувати тактики розумного переконання.

\section{Соціальний критерій}

Творчий рівень:

- дитина активно бере участь у житті колективу, стійко зацікавлена заходами, захоплюється всіма новими ідеями;

- виявляє активну готовність і вміння взаємодіяти з іншими: слухати іншого, миритися, вибачатися, вибачати, не ображатися і не ображати, співчувати, надавати допомогу та просити про неї;

- вміє домовлятися про спільну роботу 3 іншими, планувати та контролювати діяльність групи, розподіляти обов'язки, конструювати відносини у групі, радіти спільному результату;

- співвідносить свої інтереси 3 бажаннями інших дітей під час спільної партнерської діяльності.

Адаптивний рівень:

- ситуативно бере участь у житті колективу, зацікавленість заходами нестійка, захоплюється окремими новими ідеями;

- виявляє ситуативну готовність і вміння взаємодіяти 3 іншими: слухати іншого, миритися, вибачатися, вибачати, не ображатися і не ображати, співчувати, надавати допомогу та просити про неї, розподіляти обов'язки, радіти спільному результату;

- за потреби домовляється про спільну роботу з іншими, планує та контролює діяльність групи, розподіляє обов’язки, конструює відносини у групі;

- співвідносить свої інтереси з бажаннями інших дітей під час спільної партнерської діяльності.

Елементарний рівень:

- не бере участь у житті колективу, зацікавленість заходами та новими ідеями відсутня;

- не проявляє вміння взаємодіяти 3 іншими: слухати іншого, миритися, вибачатися, вибачати, не ображатися і не ображати, співчувати, надавати допомогу та просити про неї, розподіляти обов'язки, радіти спільному результату;

- не домовляється про спільну роботу з іншими, не планує та не контролює діяльність групи, не розподіляє обов’язки, не конструює 
відносини у групі;

- не співвідносить свої інтереси з бажаннями інших дітей під час спільної партнерської діяльності.

Висновки. Проведене дослідження дозволило виокремити чотири основні критерії та показники рівня розвитку лідерського потенціалу дітей старшого дошкільного віку: особистісний (щирокий світогляд, базові особистісні якості (важливі для лідерства), здатність особистості до аналізу результатів діяльності та подальшого формулювання перспектив), креативно-діяльнісний (прагнення лідерської позиції $у$ дитячій спільноті (вмотивованість), відчуття новизни та креативний nідхід до діяльності, лідерська поведінка), комунікативний (здатність до налагодження комунікаиії, чутливість до емоиій свойх власних та оточення), соціальний (здатність до партнерської взаємодї та досягнення взаєморозуміння, адаптивність поведінки). На цій основі схарактеризовано рівні розвитку лідерського потенціалу дітей старшого дошкільного віку: творчий, адаптивний, елементарний.

\section{Перспективи подальших досліджень.}

Для створення моделі розвитку лідерського потенціалу потрібно провести емпіричне дослідження із залученням вказаних критеріїв i показників. 


\section{Список літератури}

Алфімов, Д. (2014). Теоретико-методологічні основи виховання лідерських якостей школярів. Гуманізачія навчально-виховного прочесу, 14, 160-165.

Безсонова, О. К. (2020). Дефініційний аналіз поняття "лідерський потенціал дошкільника". Гуманізащія навчально-виховного прочесу, 1, 17-25. DOI: https://doi.org/10.31865/2077-1827.1(99)2020.198089

Буряк, Т. (2009). Сучасні підходи до лідерства. Київ: Наукова думка.

Волківська, Д. А. (2016). Розвиток лідерського потенціалу студентського активу в університетському середовищі. (Дис. канд. пед. наук). Київський університет імені Бориса Грінченка, Київ.

Гавриш, Н., Безсонова, О., Безрукова, О., \& Воронов, В. (2020). Лідер живе у кожному. Париіальна програма для ЗДО по формуванню лідерського потенціалу дітей дошкільного віку. Отримано leader.com/sites/default/files/2.pdf

Гавриш, Н., \& Воронов, В. (2016). Азбука лідера. Київ: Слово.

Гавриш, Н. (2017). Лідерство - риса активних, або як і навіщо плекати лідерів змалку. Дошкільне виховання, 3, 2-6.

Головешко, Б. Р. (2016). Теоретичне обтрунтування педагогічних умов формування лідерських якостей майбутніх фахівців з адміністративного менеджменту у вищих навчальних закладах. отримано https://www.vspu.edu.ua/faculty/imad/files/z/Z 47.pdf\#page=138

Драч, I. I. (2015). Лідерство і командність в управлінні навчальним закладом. ScienceRise, 2(1), 63-67. http://nbuv.gov.ua/UJRN/texc и2015 2(1) 13

Іванова, В. (2014). Проблема лідерства в колективі дітей дошкільного віку. Науковий вісник Ужгородського національного університету. Серія : Педагогіка. Соиіальна робота, 32, 78-81. Отрмано 3: http://nbuv.gov.ua/UJRN/Nvuuped_2014_32_28

Калашнікова, С. А. (2010а). Актуальність лідерства в умовах сучасних суспільних трансформацій та його вплив на професійну підготовку управлінців. Освітологічний дискурс, 1, 75-89.

Калашнікова, С. А. (2010b). Освітня парадигма професіоналізаиії управління на засадах лідерства. Отримано 3: https://core.ac.uk/download/pdf/32308175.pdf

Клепко, С., \& Литвинюк, Л. (2012). Формування лідерської компетентності в школі: навчальний посібник-довідник. Полтава: ПОІППО.

Кові, С. Р., Кові, Ш., Самерз, М., \& Хетч, Д. К. (2016). Лідер у мені. Формування культури лідерства у школах світу. Київ: Едіпрес Україна.

Кращенко, Ю. П. (2011). Виховання лідерських якостей майбутніх учителів у Полтавському молодіжному проекті "Школа місцевого i студентського самоврядування "Лідер майбутнього"'. Отримано з: http://dspace.pnpu.edu.ua/bitstream/123456789/2551/1/Kraschenko.pdf

Локошко, Л. А. (2008). Як виростити лідера. Виховна робота в школі, 12, 15-25. 
Локшин, В. С. (2013). Формування лідерських якостей майбутніх менеджерів соціокультурної діяльності в контексті процесу модернізації вищої освіти. Духовність особистості: методологія, теорія і практика, 1(54), 109-120.

Луговий, В., Калашнікова, С., Слюсаренко, О., \& Таланова, Ж. (2014). Автономія та лідерство в європейському просторі вищої освіти. Вища освіта Украӥни, 1, $14-20$.

Мараховська, Н. В. (2009). Педагогічні умови формування лідерських якостей майбутніх учителів у процесі навчання дисциплін гуманітарного ичиклу. Отримано 3: https://mydisser.com/dfiles/97792221.doc

Мороз, В. П. (2019). Лідерство як наукова проблема. Вісник Луганського національного університету імені Тараса Шевченка. DOI: https://doi.org/10.12958/2227-2844-2019-1(324)-1-99-110

Нестуля, С. І. (2010). Лідерство - необхідна умова і об'єктивна потреба в нових реаліях сучасного світу. Науковий вісник Полтавського університету економіки $i$ торгівлі. Серія : Економічні науки, 4(2), 119-123. Отримано 3: http://nbuv.gov.ua/UJRN/Nvpusk_2010 4(2) 26.

Петрочко, Ж. В. (2014). Сутність і функціональна роль соціальної ініціативності у структурі лідерства підлітків. Теоретико-методичні проблеми виховання дітей та учнівської молоді, 18(2), 143-150.

Піроженко, Т., Хартман, О., Палієнко, К., \& Паленко, М. (2016). Методичний посібник до парціальної програми з розвитку соціальних навичок ефективної взаємодії дітей від 4 до 6-7 років "Вчимося жити разом". Отримано 3: https://mon.gov.ua/storage/app/media/doshkilna/programi/1.pdf

Приходько, М. (2008). Учнівське самоврядування в сучасному вимірі. Харків: Основа.

Прохоренко, Т. Г., Зборовська, О. П., \& Носирєва, Г. А. (2008). Лідерство як форма самоствердження особистості в малій групі. Вісник Міжнародного слов 'янського університету. Серія: Соціологічні науки, 11(1), 8-13.

Романовський, О., \& Резнік, С. (2017). Аналіз результатів педагогічного експерименту розвитку лідерського потенціалу у студентів вищого технічного навчального закладу. Університети $i$ лідерство, 1. Отримано 3: http://nbuv.gov.ua/UJRN/univlead_2017_1_10.

Ротко, О. М. (2017). Діагностика розвитку лідерських якостей дітей молодшого підліткового віку. У Проблеми та перспективи розвитку освіти. Матеріали III Міжнародної науково-практичної конферениії (м. Львів, 30-31 березня 2017 року). (сс. 166-169). Херсон : Гельветика, 2017. 166-169.

Садохіна, К. С. (2010). Психолого-педагогічні умови формування лідерських якостей підлітків. Отримано 3: http://horizons.vpi.kpi.ua/index.php/22276246/article/download/161942/160924

Семенов, А. А. (2014). Виховання лідерських якостей у молодших иколярів засобами рухливих ігор (Автореф. дис. … канд. наук). Отримано 3: https://nauka.udpu.edu.ua/wp-content/uploads/Novuny/26.02.14/1.pdf

Скібіцька, Л. (2009). Лідерство та стиль роботи менеджера: навчальний посібник. Київ: Центр учбової літератури. 
Сурай, I. (2011). Еліти в державному управлінні: феномен лідерства. Вісник Національної Академії Державного управління при Президентові України, 4, 7077.

Татенко, В. (2006). Типологія лідерства. Психолог, 34, 12-14.

Тихомирова, О. (2009). Виховання лідера. Шкільний світ, 8, 19-23.

Шевчук, Л. М. (2016). Управлінсько-лідерські здібності молодших школярів: сутність та специфіка. Український педагогічний журнал, 4, 18-23. Отримано з: http://nbuv.gov.ua/UJRN/ukrpj_2016_4_5.

Ягодінкова, В. (2009). Виховання лідерів. Виховна робота в школі, 10, 2-36.

Яхнін, Я. К. (2010). Сучасні підходи до виховання лідера. Київ : Наукова думка.

Яценко, О. М. (2016). Лідерські якості в структурі складових компетентностей менеджерів. Молодий вчений, 6(33), 496-501. Отримано 3: http://repository.kpi.kharkov.ua/handle/KhPI-Press/34936

Balci, Ye. (2017). Coaching as a modern method of development of leadership potential in university. Університети $i$ лідерство, 1. Retrived from: http://nbuv.gov.ua/UJRN/univlead $2017 \quad 13$.

Blank, W. (1995). The Natural Laws of Leadership. New York: AMACOM.

\section{References}

Alfimov, D. (2014). Teoretyko-metodolohichni osnovy vykhovannya liders'kykh yakostey shkolyariv [Theoretical and methodological bases of education of leadership qualities of schoolchildren]. Humanizatsiya navchal'no-vykhovnoho protsesu [Humanization of the educational process], 14, 160-165. [in Ukrainian].

Bezsonova, O. K. (2020). Definitsiynyy analiz ponyattya "liders'kyy potentsial doshkil'nyka" [Definitional analysis of the concept of "leadership potential of the preschooler"]. Humanizatsiya navchal'no-vykhovnoho protsesu [Humanization of the educational process], 1, 17-25.

DOI: https://doi.org/10.31865/2077-1827.1(99)2020.198089. [in Ukrainian].

Buryak, T. (2009). Suchasni pidkhody do liderstva [Modern approaches to leadership]. Kyiv: Naukova dumka. [in Ukrainian].

Volkivs'ka, D. A. (2016). Rozvytok liders'koho potentsialu students'koho aktyvu v universytets'komu seredovyshchi [Development of leadership potential of student assets in the university environment]. (Candidate's thesis). Kyivskyi universtet imeni Borysa Hrinchenka, Kyiv. [in Ukrainian].

Havrysh, N., Bezsonova, O., Bezrukova, O., \& Voronov, V. (2020). Lider zhyve u kozhnomu. Partsial'na prohrama dlya ZDO po formuvannyu liders'koho potentsialu ditey doshkil'noho viku [The leader lives in everyone. Partial program for ZDO on formation of leadership potential of preschool children]. Retrieved from: https://kidsprogram.mr-leader.com/sites/default/files/2.pdf. [in Ukrainian].

Havrysh, N., \& Voronov, V. (2016). Azbuka lidera [The alphabet of the leader]. Kyiv: Slovo. [in Ukrainian]. 
Havrysh, N. (2017). Liderstvo - rysa aktyvnykh, abo yak i navishcho plekaty lideriv zmalku [Leadership is a trait of active, or how and why to nurture leaders from an early age]. Doshkil'ne vykhovannya [Preschool upbringing], 3, 2-6. [in Ukrainian].

Holoveshko, B. R. (2016). Teoretychne obgruntuvannya pedahohichnykh umov formuvannya liders'kykh yakostey maybutnikh fakhivtsiv $z$ administratyvnoho menedzhmentu $u$ vyshchykh navchal'nykh zakladakh [Theoretical substantiation of pedagogical conditions of formation of leadership qualities of future specialists in administrative management in higher educational institutions]. Retrieved from: https://www.vspu.edu.ua/faculty/imad/files/z/Z_47.pdf\#page=138. [in Ukrainian].

Drach, I. I. (2015). Liderstvo i komandnist' v upravlinni navchal'nym zakladom [Leadership and teamwork in the management of the educational institution]. ScienceRise, 2(1), 63-67. Retrieved from: http://nbuv.gov.ua/UJRN/texc_2015_2(1)_13. [in Ukrainian].

Ivanova, V. (2014). Problema liderstva v kolektyvi ditey doshkil'noho viku [The problem of leadership in the team of preschool children]. Naukovyi visnyk Uzhhorodskoho natsionalnoho universytetu. Seriia : Pedahohika. Sotsialna robota [Scientific Bulletin of Uzhhorod National University. Series: Pedagogy. Social work], 38, 78-81. Retrieved from: http://nbuv.gov.ua/UJRN/Nvuuped_2014_32_28 [in Ukrainian].

Kalashnikova, S. A. (2010a). Aktual'nist' liderstva v umovakh suchasnykh suspil'nykh transformatsiy ta yoho vplyv na profesiynu pidhotovku upravlintsiv [The relevance of leadership in modern social transformations and its impact on the training of managers]. Osvitolohichnyy dyskurs [Educological discourse], 1, 75-89. [in Ukrainian].

Kalashnikova, S. A. (2010b). Osvitnya paradyhma profesionalizatsiyi upravlinnya na zasadakh liderstva [Educational paradigm of professionalization of management on the basis of leadership]. Retrieved from: https://core.ac.uk/download/pdf/32308175.pdf. [in Ukrainian].

Klepko, S., \& Lytvynyuk, L. (2012). Formuvannya liders'koyi kompetentnosti v shkoli: navchal'nyy posibnyk-dovidnyk [Formation of leadership competence in school: an initial guide]. Poltava: POIPPO. [in Ukrainian].

Kovi, S. R., Kovi, Sh., Samerz, M., \& Khetch, D. K. (2016). Lider u meni. Formuvannya kul'tury liderstva u shkolakh svitu [I have a leader. Forming a culture of leadership in schools around the world]. Kyiv: Edipres Ukrayina. [in Ukrainian].

Krashchenko, Yu. P. (2011). Vykhovannya liders'kykh yakostey maybutnikh uchyteliv u Poltavs'komu molodizhnomu proekti "Shkola mistsevoho $i$ students'koho samovryaduvannya "Lider maybutn 'oho"'" [Education of leadership qualities of future teachers in the Poltava youth project "School of local and student self-government "Leader of the future"']. Retrieved http://dspace.pnpu.edu.ua/bitstream/123456789/2551/1/Kraschenko.pdf. [in Ukrainian].

Lokoshko, L. A. (2008). Yak vyrostyty lidera [How to grow a leader]. Vykhovna robota $v$ shkoli [Educational work at school], 12, 15-25. [in Ukrainian].

Lokshyn, V. S. (2013). Formuvannya liders'kykh yakostey maybutnikh menedzheriv sotsiokul'turnoyi diyal'nosti v konteksti protsesu modernizatsiyi vyshchoyi osvity [Formation of leadership qualities of future managers of socio-cultural activities in the context of the process of modernization of higher education]. Dukhovnist' osobystosti: 
metodolohiya, teoriya i praktyka [Spirituality of personality: methodology, theory and practice], 1(54), 109-120. [in Ukrainian].

Luhovyy, V., Kalashnikova, S., Slyusarenko, O., \& Talanova, Zh. (2014). Avtonomiya ta liderstvo $\mathrm{v}$ yevropeys'komu prostori vyshchoyi osvity [Autonomy and leadership in the European Higher Education Area]. Vyshcha osvita Ukrayiny [Higher education in Ukraine], 1, 14-20. [in Ukrainian].

Marakhovs'ka, N. V. (2009). Pedahohichni umovy formuvannya liders'kykh yakostey maybutnikh uchyteliv u protsesi navchannya dystsyplin humanitarnoho tsyklu [Pedagogical conditions for the formation of leadership qualities of future teachers in the process of teaching disciplines of the humanities]. Retrieved from: https://mydisser.com/dfiles/97792221.doc. [in Ukrainian].

Moroz, V. P. (2019). Liderstvo yak naukova problema [Leadership as a scientific problem]. Visnyk Luhans 'koho natsional'noho universytetu imeni Tarasa Shevchenka [Bulletin of Luhansk Taras Shevchenko National University], 19(1). DOI: https://doi.org/10.12958/2227-2844-2019-1(324)-1-99-110. [in Ukrainian].

Nestulya, S. I. (2010). Liderstvo - neobkhidna umova i ob’yektyvna potreba $v$ novykh realiyakh suchasnoho svitu [Leadership is a necessary condition and an objective need for the new realities of the modern world]. Naukovyi visnyk Poltavskoho universytetu ekonomiky i torhivli. Seriia : Ekonomichni nauky [Scientific Bulletin of Poltava University of Economics and Trade. Series: Economic Sciences], 4(2), 119-123. Retrieved from: http://nbuv.gov.ua/UJRN/Nvpusk_2010_4(2)_26. [in Ukrainian].

Petrochko, Zh. V. (2014). Sutnist' i funktsional'na rol' sotsial'noyi initsiatyvnosti u strukturi liderstva pidlitkiv [The essence and functional role of social initiative in the leadership structure of adolescents]. Teoretyko-metodychni problemy vykhovannya ditey ta uchnivs'koyi molodi [Theoretical and methodological problems of raising children and students], 18(2), 143-150. [in Ukrainian].

Pirozhenko, T., Khartman, O., Paliyenko, K., \& Palenko, M. (2016). Metodychnyy posibnyk do partsial'noyi prohramy z rozvytku sotsial'nykh navychok efektyvnoyi vzayemodiyi ditey vid 4 do 6-7 rokiv "Vchymosya zhyty razom" [Methodical guide to the partial program for the development of social skills of effective interaction of children from 4 to 6-7 years "Learning to live together"]. Retrieved from: https://mon.gov.ua/storage/app/media/doshkilna/programi/1.pdf. [in Ukrainian].

Prykhod'ko, M. (2008). Uchnivs'ke samovryaduvannya v suchasnomu vymiri [Student selfgovernment in the modern dimension]. Kharkiv: Osnova. [in Ukrainian].

Prokhorenko, T. H., Zborovs'ka, O. P., \& Nosyryeva, H. A. (2008). Liderstvo yak forma samostverdzhennya osobystosti $\mathrm{v}$ maliy hrupi [Leadership as a form of selfaffirmation in a small group]. Visnyk Mizhnarodnoho slov'yans'koho universytetu. Seriya: Sotsiolohichni nauky [Bulletin of the International Slavic University. Series: Sociological Sciences], 11(1), 8-13. [in Ukrainian].

Romanovs'kyy, O., \& Reznik, S. (2017). Analiz rezul'tativ pedahohichnoho eksperymentu rozvytku liders'koho potentsialu u studentiv vyshchoho tekhnichnoho navchal'noho zakladu [Analysis of the results of the pedagogical experiment of leadership development in students of higher technical educational institution]. Universytety $i$ liderstvo [University and leadership], 1. Retrieved from: http://nbuv.gov.ua/UJRN/univlead_2017_1_10. [in Ukrainian]. 
Rotko, O. M. (2017). Diahnostyka rozvytku liders'kykh yakostey ditey molodshoho pidlitkovoho viku [Diagnosis of the development of leadership qualities of young adolescents]. U Problemy ta perspektyvy rozvytku osvity. Materialy III Mizhnarodnoyi naukovo-praktychnoyi konferentsiyi (m. L'viv, 30-31 bereznya 2017 roku) [Problems and prospects of education development. Proceedings of the III International Scientific and Practical Conference (Lviv, March 30-31, 2017)] (pp. 166-169). Kherson : Hel'vetyka. [in Ukrainian].

Sadokhina, K. S. (2010). Psykholoho-pedahohichni umovy formuvannya liders'kykh yakostey pidlitkiv [Psychological and pedagogical conditions for the formation of leadership qualities of adolescents]. Retrieved from: http://horizons.vpi.kpi.ua/index.php/22276246/article/download/161942/160924. [in Ukrainian].

Semenov, A. A. (2014). Vykhovannya liders'kykh yakostey u molodshykh shkolyariv zasobamy rukhlyvykh ihor (Avoref. dys. ... kand. nauk) [Education of leadership qualities in junior schoolchildren by means of mobile games] (Extended abstract of candidate's thesis). Retrieved from: https://nauka.udpu.edu.ua/wpcontent/uploads/Novuny/26.02.14/1.pdf. [in Ukrainian].

Skibits'ka, L. (2009). Liderstvo ta styl' roboty menedzhera: navchal'nyy posibnyk [Leadership and managerial style: a textbook]. Kyiv: Tsentr uchbovoyi literatury. [in Ukrainian].

Suray, I. (2011). Elity $\mathrm{v}$ derzhavnomu upravlinni: fenomen liderstva [Elites in public administration: the phenomenon of leadership]. Visnyk Natsional'noyi Akademiyi Derzhavnoho upravlinnya pry Prezydentovi Ukrayiny [Bulletin of the National Academy of Public Administration under the President of Ukraine], 4, 70-77. [in Ukrainian].

Tatenko, V. (2006). Typolohiya liderstva [Typology of leadership]. Psykholoh [Psychologist], 34, 12-14. [in Ukrainian].

Tykhomyrova, O. (2009). Vykhovannya lidera [Education of a leader]. Shkil'nyy svit [School world], 8, 19-23. [in Ukrainian].

Shevchuk, L. M. (2016). Upravlins'ko-liders'ki zdibnosti molodshykh shkolyariv: sutnist' ta spetsyfika [Management and leadership abilities of junior schoolchildren: essence and specifics]. Ukrainskyi pedahohichnyi zhurnal [Ukrainian pedagogical journal], 4, 1823. Retrieved from: http://nbuv.gov.ua/UJRN/ukrpj 20164 5. [in Ukrainian].

Yahodinkova, V. (2009). Vykhovannya lideriv [Education of leaders]. Vykhovna robota $v$ shkoli [Educational work at school], 10, 2-36. [in Ukrainian].

Yakhnin, Ya. K. (2010). Suchasni pidkhody do vykhovannya lidera [Education of leaders]. Kyiv: Naukova dumka. [in Ukrainian].

Yatsenko, O. M. (2016). Liders'ki yakosti v strukturi skladovykh kompetentnostey menedzheriv [Modern approaches to the education of a leader]. Molodyi vchenyi [Young Scientist], 6(33), 496-501. Retrieved from: http://repository.kpi.kharkov.ua/handle/KhPI-Press/34936. [in Ukrainian].

Balci, Ye. (2017). Coaching as a modern method of development of leadership potential in university. Universytety i liderstvo [Universities and leadership], 1. Retrived from: http://nbuv.gov.ua/UJRN/univlead_2017_1_3.

Blank, W. (1995). The Natural Laws of Leadership. New York: AMACOM. 


\section{Безсонова Ольга Костянтинівна}

кандидат педагогічних наук

комунальний дошкільний навчальний заклад (ясла-садок) № 67 «Сонячний» загального типу Краматорської міської ради, завідувач

84331, Донецька обл, м. Краматорськ, вул. Марії Приймаченко, 23

$+380665662150$

ORCID 0000-0003-0897-3029

74bessonov@gmail.com

\section{Olga Bezsonova}

candidate of pedagogical sciences

municipal preschool educational institution (kindergarten) № 67 “Sunny” general type of Kramatorsk City Council, head 84331, Donetsk region, Kramatorsk, Marii Priimachenko str., 23

$+380665662150$

ORCID 0000-0003-0897-3029

74bessonov@gmail.com 